\title{
A Tribute to Laurie Lynn Consaul, 1960-2012
}

\author{
LYNN GILLESPIE
}

Canadian Museum of Nature, P.O. Box 3443, Station D, Ottawa, Ontario K1P 6P4 Canada; email: LGILLESPIE@mus-nature.ca

Gillespie, Lynn. 2013. A tribute to Laurie Lynn Consaul, 1960-2012. Canadian Field-Naturalist 127(4): 352-357.

Born in Bracebridge, Ontario, on 22 March 1960, Laurie Lynn Consaul grew up in Fort William and Kapuskasing in northern Ontario and, after the age of 11 , in Alliston in southern Ontario. She completed her undergraduate degree in plant sciences at the University of Western Ontario (UWO) in London in 1983. Her honours research thesis was Changes in Chloroplast Proteins During Leaf Development in Vicia faba L. (Fabaceae).

Switching her research interests to plant systematics, a field that would become her lifelong passion, Laurie moved to Ottawa to continue her studies under John McNeill at the University of Ottawa. In 1988, she completed her M.Sc. Her thesis was The Biosystematics of Polygonum lapathifolium L. (Polygonaceae) in North America. Returning to the University of Western Ontario (1986-1990), Laurie worked for Jim Phipps in a variety of roles as research assistant, helping with his systematic research on Crataegus, as assistant herbarium curator, and as assistant curator of the UWO Sherwood Fox Arboretum. Her work on Crataegus and Polygonum, two taxonomically difficult genera, marked the beginning of a passion for challenging taxa.

In 1990, Laurie moved back to Ottawa to begin work as a research assistant at the Canadian Museum of Nature, the start of a 22-year career with the Museum. Working within the Botany group, Laurie was instrumental in the success of numerous research projects, varying in subject from lichens to grasses and other arctic plants. Working with Irwin Brodo, she learned much about lichens and assisted in preparing and editing his monumental book Lichens of North America. Laurie worked extensively with Susan Aiken on arctic grasses, the grass genus Festuca, and the arctic flora. As project assistant, author, and editor of the interactive $\mathrm{CD}$ and web-based Flora of the Canadian Arctic Archipelago (Aiken et al. 2007), she was instrumental in seeing this project through to completion.

Over her many years at the Museum, Laurie became a competent and experienced systematist, gaining a broad knowledge of botany and exceptional laboratory skills. She displayed a dedication to collections-based herbarium research. Passionate about research and extremely hardworking, she put in long hours when a project piqued her interest (which was often!). Detail oriented, Laurie kept voluminous notes, whether in the field or the lab. I have many memories of Laurie writ-

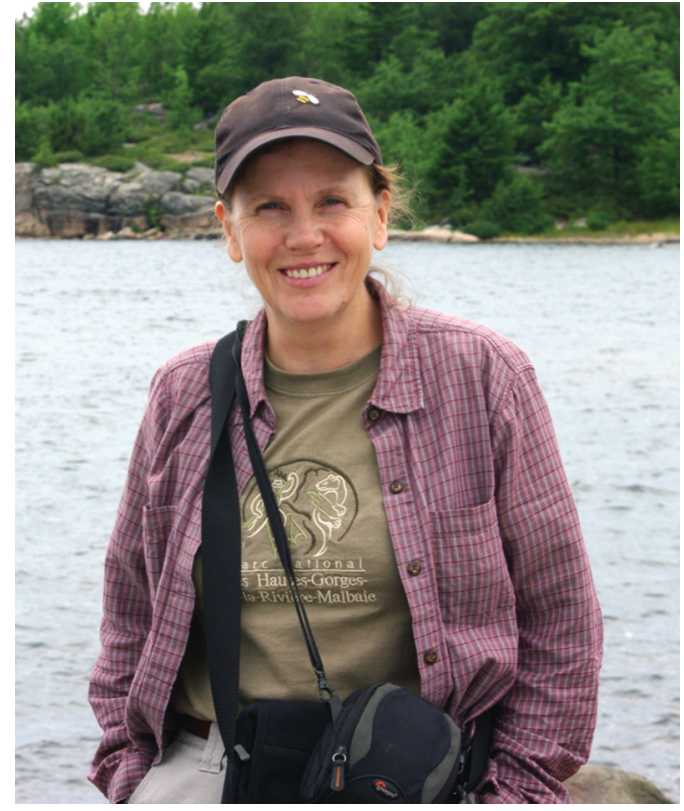

FIgURE 1. Laurie Consaul, near Parry Sound on Georgian Bay, Ontario, summer 2010. Photo: M. Armstrong.

ing her field notes and diary long into the cold arctic night while snuggled in her sleeping bag as I drifted off to sleep, exhausted.

With determination (and bravery!) Laurie decided to go back to school when she was in her 40s to obtain her $\mathrm{Ph}$.D. Laurie took a leave of absence from the Museum to attend McGill University (2002-2008) under the supervision of Marcia Waterway at the Macdonald Campus. Through a combination of hard work and creativity, Laurie obtained her own funding through an Industrial Postgraduate Scholarship from the Natural Sciences and Engineering Research Council of Canada (NSERC) and several smaller awards and grants, allowing her to work on the systematics of Puccinellia, a perplexing group of arctic grasses that had long fascinated her.

Laurie combined painstaking growth experiments with equally detailed molecular and morphological analyses, successfully untangling the complex evolution of the diploid and polyploid species in the Canadian 


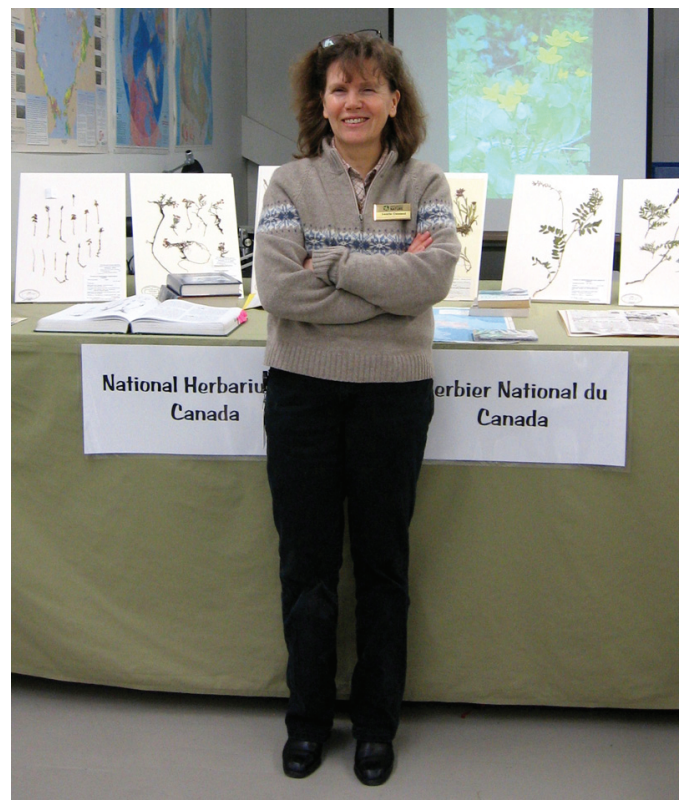

FIgURE 2. Laurie Council at arctic plant research display at Natural Heritage Building. Canadian Museum of Nature, Gatineau (Alymer) Quebec, April 2011. Photo: L. Gillespie.

Arctic. Graduating in 2008, Laurie produced a superb dissertation, The Role of Polyploidy in the Evolution and Systematics of Arctic Puccinellia (Poaceae). The resulting series of papers is undoubtedly the most in-depth systematic study of any genus in the Canadian Arctic (Consaul et al. 2008a, 2008b, 2008c, 2010a, b).

Laurie was in my mind first and foremost an arctic botanist. We first met in the summer of 1991 at Alexandra Fiord, Ellesmere Island (where I was assisting at an entomology camp, my first trip to the Arctic). Laurie had helicoptered in for the afternoon to collect a few grasses. We both were astonished to come across another botanist so unexpectedly in so remote a place: I was delighted to meet another botanist passionate about arctic plants, and Laurie was pleased to meet someone who could direct her to her species of interest. We both caught the arctic bug that summer. Laurie had recently started her position as research assistant at the Canadian Museum of Nature, and I wouldn't arrive at the Museum for another three years. Although we didn't suspect it at the time, we would eventually spend 6 summers together in the Arctic.

I have the most wonderful memories of these summers with Laurie in the Arctic: long hikes over the open tundra across wet meadows and up mountains searching for interesting plants. Always on the lookout for birds, Laurie would marvel at the bird nests we unexpectedly found on the tundra and linger by small lakes, binoculars in hand. We enjoyed dinner together in the open air, hands warming around mugs of tea, contem- plating the tundra and the sky. We spent hours upon hours in a small dome tent examining and pressing our plant collections, eventually emerging, unfolding our stiff legs, to enjoy the midnight sun, the long arctic twilight, and the wide-open spaces.

I remember well Laurie's determined and somewhat confused looks when she was examining her grasses. She chose to study a group of arctic grasses (genus Puccinellia) that was so taxonomically complex that few others had studied the group, and none to the degree that she would. I remember her delight when she discovered possible new species. One of these indeed was a new species, which she went on to describe and publish, naming it Puccinellia banksiensis after the island where she first collected it. Another summer several years later, on Victoria Island, we were hiking back to camp from the coast after a very long day and lots of plant collecting. Laurie and I were lagging behind the group, exhausted, when Laurie knelt down, shotgun slung over her shoulder (our protection against possible Polar Bears, Ursus maritimus). She had just discovered a new locality for Puccinellia banksiensis, the first for Victoria Island, and she was absolutely delighted. Only Laurie would have noticed this tiny inconspicuous grass while hiking for hours over thousands upon thousands of tiny grasses. To the rest of us they all looked so similar.

I vividly remember sitting with Laurie on a hillside on Melville Island - Laurie and I likely the only humans on this immense High Arctic island-watching an Arctic Wolf (Canis lupus arctos) family with three young pups. Later that same summer, we weathered our worst storm together at the Polar Bear Pass field station on Bathurst Island, enduring 36 hours of violent winds and horizontal snow with all radio communication down (this was before the days of satellite telephones). I convinced Laurie not to venture outside-I really thought she might blow away in the strong winds. That was her personality: although petite, she was tough, and never complained, preferring a smile through the worst the field could throw her way. Laurie was an excellent field companion and an extremely dedicated field botanist who loved the Arctic.

Laurie's first research trip to the Arctic was with Susan Aiken in 1990 to Ivvavik National Park of Canada in northern Yukon. Her last arctic adventure was in 2010 to the Belcher Islands in Hudson Bay, as the botanist on an ethnobotanical study. During the years in between, Laurie travelled throughout the Canadian Arctic, from Quttinirpaaq National Park of Canada on northern Ellesmere Island to Tuktut Nogait National Park of Canada on the mainland Northwest Territories, and from Tuktoyaktuk to the Savage Islands off the southeastern tip of Baffin Island. In all, Laurie spent 11 field seasons in the Canadian Arctic, including 8 Canadian Museum of Nature field expeditions. As part of her Ph.D. program, Laurie led 2 arctic field expeditions, and from 2002 to 2005 she also undertook re- 
search on the use of native plant species to stabilize and revegetate mine tailings at Voisey Bay, Labrador, Newfoundland and Labrador. Laurie's collections from the Arctic and elsewhere are listed in Table 1; she also made many other collections as part of a team on other expeditions.

Laurie's love of nature was by no means limited to vascular plants or the Arctic. She was a passionate birder, active with the Ottawa Field-Naturalists' Club (OFNC), partaking in local annual bird counts, competing in bird count competitions, and always on the watch for interesting birds. Wherever Laurie travelled, in the Arctic or on one of her many vacations with her husband, Mark, to faraway places, she delighted in nature, from lichens and mosses to the largest trees, from insects to birds, meticulously observing and always recording detailed notes.

Laurie was an active member of the OFNC starting in the early 1990s, when she moved back to Ottawa. She was a member of the Birds Committee from 1993 to 2002 and then again in 2010-2011. Serving as recording secretary for all of these years, she had a reputation for dedication, detail, and a job well done.

As a member of the OFNC Macoun Club Committee, Laurie took part in almost every planning meeting from 1992 to 1999 (five meetings a year in those days) and helped organize the weekly program for young naturalists. She lined up many good speakers; the Canadian Museum of Nature photocopy machine was reportedly a great place to engage her colleagues in conversation and persuade them to talk to the young members. In 1992, Laurie was part of a small subcommittee that established the field-trip safety practices for the Macoun Club still in use. From 1999 until

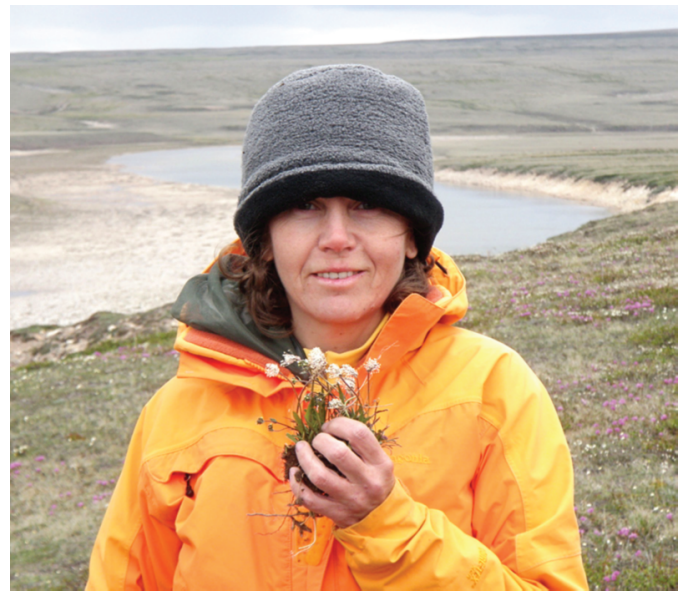

FIgURE 3. Laurie Consaul with Plantago canescens, Hornaday River, in Tuktut National Park, Northwest Territories, July 2009. Photo: L. Gillespie.

2002, she served as liaison with the Museum, which then housed the Macoun Club collections and library and provided meeting space. In the late 1990s, she took part in the Baillie Birdathon (the oldest sponsored bird count in North America) and directed her share of the funds raised to the Macoun Club, a welcome donation used to buy research equipment. Although less involved after the 1990s, Laurie always remained interested in what was going on in the Macoun Club.

As a member of the Motherflickers team from 1996 to 2003, Laurie took part in the annual Taverner Cup, a 24-hour competitive birdathon in eastern Ontario

TABle 1. Laurie Consaul's series of collections held at the National Herbarium of Canada, Canadian Museum of Nature (CAN): a preliminary list, including year, number range, and localities.

\begin{tabular}{lll}
\hline \hline Year & Collection numbers & Location \\
\hline 1984 & $1-454$ & Ontario; New York (U.S.A.) \\
1985 & $463-773$ & Ontario; Quebec; England \\
1990 & $813-1029$ & Inuvik (Nunavut), Ivvavik National Park of Canada (Yukon); Virginia (U.S.A.) \\
1991 & $1040-1054$ & Ellesmere Island and Baffin Island (Nunavut) \\
1992 & $1055-1066$ & Nova Scotia; Churchill (Manitoba) \\
1993 & $1080-1084$ & Baffin Island (Nunavut) \\
1994 & $1085-1094$ & Calgary (Alberta); Kimberley (British Columbia) \\
1995 & $1178-1204$ & Gatineau (Quebec) \\
1997 & $1100-1177$ & Cambridge Bay (Nunavut); Oxford Station (Ontario); Gatineau (Quebec) \\
1998 & $2004-2041,2390$ & Ottawa (Ontario); Gatineau (Quebec); Burritts Rapids (Ontario) \\
1999 & $2042-2330$ & Ontario; Ellesmere Island, Axel Heiberg Island, Baffin Island, Devon Island, and \\
& & Cornwallis Island (Nunavut) \\
2001 & $2402-2463$ & Melville Island (Nunavut); New Mexico (U.S.A.) \\
2002 & $2500-2732$ & Voisey Bay, Labrador (Newfoundland and Labrador) \\
2003 & $2733-2944$ & Voisey Bay, Labrador (Newfoundland and Labrador); Banks Island (Northwest \\
& & Territories); Ellesmere Island and Axel Heiberg Island (Nunavut) \\
2004 & $2970-3212$ & Voisey Bay, Labrador (Newfoundland and Labrador); Resolute, Beechey Island, \\
& & Cunningham Inlet, and Iqaluit (Nunavut); \\
2005 & $3222-3244$ & Voisey Bay, Labrador (Newfoundland and Labrador) \\
2010 & $3502-4345$ & Belcher Islands (Nunavut) \\
\hline \hline
\end{tabular}


and western Quebec. Team members Christine Lewis and Jean Wylie recall Laurie as their note taker and archivist par excellence, keeping the team awake with food and song during the long hours. Motherflickers won four trophies in the recreational class, the Fothergill Trophy (for the highest number of species seen in a 24-hour period) in 1997 and the Judith Wilks Trophy (second highest number of species) in 2000, 2001, and 2002. Laurie was also actively involved with both of the Ontario Breeding Bird Atlas projects, including serving as a regional coordinator for Region 22 (Kemptville) in 2001-2002.

Laurie was dedicated to plant systematics, and she was recognized internationally as an expert in arctic plants and specifically Puccinellia. She authored 30 scientific publications, 10 as first author; 6 technical reports, including a status report on Blunt-lobed Woodsia (Woodsia obtusa) for the Committee on the Status of Endangered Wildlife in Canada (COSEWIC), and an additional 5 popular natural history articles (see list of publications).

In addition to her studies on arctic Puccinellia cited above, she coauthored the very useful treatments of Puccinellia for the Flora of North America and the Manual of Grasses for North America (Davis and Consaul 2007a, 2007b). Laurie was a long-time member of the Canadian Botanical Association (a student member in the 1980s and a regular member from 1994), serving as secretary of the Systematics and Phytogeography section from 1995 to 1998 and as association secretary from 2009 to 2011.

In 2011, Laurie accepted a position as assistant professor in the Biology Department at Memorial University, St. John's, Newfoundland and Labrador. This was to be the pinnacle of her career, a goal Laurie had worked so hard and with such determination to obtain.

Just prior to her scheduled move to St. John's, Laurie became ill while attending the 2011 Canadian Botanical Association annual meeting in Halifax. Diagnosed with a brain tumour, she spent the next year and a half bravely fighting her illness, with the loving care and support of her husband, Mark. Laurie lost her battle with cancer on 18 December 2012. Canada lost an excellent arctic botanist and plant systematist, and many from across Canada and around the world lost a dear friend.

\section{Acknowledgements}

This tribute is a modified and expanded version of one that appeared in the Canadian Botanical Association Bulletin 46(1): 10-11. Thanks to Mark Armstrong, Ernie Brodo, Fenja Brodo, Robert Lee, Christine Lewis, and Jean Wylie for information and to Charles Gruchy, Daniel F. Brunton, George Argus, and Mark Armstrong for reading an earlier draft.

\section{Additional Comments}

Mark Armstrong has provided the following: As Laurie's illness progressed in 2012, she decided that leaving legacies to places that were a special part of her life was something important. A legacy has been given to the Sherwood Fox Arboretum at the University of Western Ontario (UWO) in London, Ontario. Laurie's time at UWO as both a student and research assistant provided her with the foundation for a life spent in the exploration of our natural world. It is the intention that a garden in Laurie's memory be established close to where she worked. To the Canadian Botanical Association (CBA), a legacy has been left to help in meeting the CBA's objective of providing for students interested in the world of botany. This annual award will be given to a student whose interest in science is acknowledged by the CBA as being deserving of recognition. In addition, an annual contribution will be given to help with travel to the Canadian Arctic for a student studying arctic natural history. The Arctic held a special place in Laurie's heart, and this funding will give students the opportunity to experience this wonderful area of our land. A third legacy was given to the Ottawa Field-Naturalists' Club. This is an organization that gave Laurie particular enjoyment. She enthusiastically contributed to the endeavours of the OFNC's work in different areas. Laurie had a long-time association with the OFNC, and her legacy will be used in a variety of ways. Annual sponsorship of the winter bird seed program will start in 2013 in Laurie's memory. A contribution will commence in 2013 to McGill University, Macdonald Campus, to be used in a way that Laurie would endorse. It was at McGill that Laurie's dream of obtaining her Ph.D. became a reality in 2008. It is intended that this annual donation be used to support and further our knowledge of biology in a place that Laurie enjoyed studying and being in.

Received 30 May 2013

Accepted 30 October 2013 


\section{Bibliography of Laurie Lynn Consaul}

\section{Publications and Technical Reports}

McNeill, J., E. A. Odell, L. L. Consaul, and D. S. Katz. 1987. American Code and later lectotypifications of Linnaean generic names dating from 1753: a case study of discrepancies. Taxon 36: 350-401.

Consaul, L. L. 1988. A biosystematic study of the Polygonum lapathifolium L. complex in North America. M.Sc. thesis, University of Ottawa, Ottawa, Ontario.

Consaul, L. L., S. I. Warwick, and J. McNeill. 1991. Allozyme variation in the Polygonum lapathifolium complex. Canadian Journal of Botany 69: 2261-2270.

Aiken, S. G., L. L. Consaul, J. I. Davis, and P. S. Manos. 1993. Systematic inferences from variation in isozyme profiles of arctic and alpine cespitose Festuca (Poaceae). American Journal of Botany 80: 76-82.

Consaul, L. L., and S. G. Aiken. 1993. Limited taxonomic value of palea intercostal characteristics in North American Festuca (Poaceae). Canadian Journal of Botany 71: $1651-1659$.

Aiken, S. G., L. L. Consaul, A. Spidle, and B. May. 1994. Allozyme and morphological observations on Festuca hyperborea, compared with $F$. baffinensis and F. brachyphylla (Poaceae) from the Canadian Arctic. Nordic Journal of Botany 14: 137-143.

Consaul, L. L. 1994. Status report on Blunt-lobed Woodsia (Woodsia obtusa (Spreng.) Torr.). Subcommittee for Plants, Committee on the Status of Endangered Wildlife in Canada (COSEWIC), Ottawa, Ontario.

Aiken, S. G., and L. L. Consaul. 1995. Leaf cross sections and phytogeography: a potent combination for identifying members of Festuca subg. Festuca and Leucopoa (Poaceae) occurring in North America. American Journal of Botany 82: 1287-1299.

Aiken, S. G., L. L. Consaul, and L. P. Lefkovitch. 1995. Festuca edlundiae (Poaceae), a High Arctic, new species compared enzymatically and morphologically with similar Festuca species. Systematic Botany 20: 374-392.

Consaul, L. L. 1995. Waterbugs take a dive at the Sportsplex. Trail and Landscape 29: 88.

Aiken, S. G., L. L. Consaul, and M. J. Dallwitz. 1996. Grasses of the Canadian Arctic Archipelago: a DELTA database for interactive identification and illustrated information retrieval. Canadian Journal of Botany 74: 1812-1825.

Aiken, S. G., C. L. McJannet, L. L. Consaul, and M. J. Dallwitz. 1997. Biodiversity among Festuca (Poaceae) in North America: diagnostic evidence from DELTA and clustering programs, and an INTKEY package for interactive, illustrated identification and information retrieval. Canadian Journal of Botany 75: 1527-1555.

Gillespie, L. J., L. L. Consaul, and S. G. Aiken. 1997. Hybridization and the origin of the arctic grass Poa hartzii (Poaceae): evidence from morphology and chloroplast DNA restriction site data. Canadian Journal of Botany 75 : 1978-1997.

Aiken, S. G., M. J. Dallwitz, C. L. McJannet, L. J. Gillespie, and L. L. Consaul. 1998a. Saxifragaceae of the Canadian Arctic Archipelago: a contribution to a DELTA database for interactive identification and illustrated information retrieval. Canadian Journal of Botany 76: 20202036.

Aiken, S. G., S. E. Gardiner, H. C. M. Bassett, B. L. Wilson, and L. L. Consaul. 1998b. Implications from SDS-PAGE analyses of seed proteins in the classification of taxa of
Festuca and Lolium (Poaceae). Biochemical Systematics and Ecology 26: 511-533.

Consaul, L. L., S. Darbyshire, and A. W. Dugal. 1998. The status of Fragile Prickly Pear Cactus (Opuntia fragilis) in Nepean, Ontario. Trail and Landscape 32: 175-181.

Aiken, S. G., M. J. Dallwitz, L. L. Consaul, C. L. McJannet, L. J. Gillespie, R. L. Boles, G. W. Argus, J. M. Gillett, P. J. Scott, R. Elven, M. C. LeBlanc, and A. E. Zamluk. 1999 onwards. Flora of the Canadian Arctic Archipelago: Descriptions, Illustrations, Identification, and Information Retrieval. (Most recent version: 29 April 2003). http://nature.ca/aaflora/data/index.htm.

Consaul, L. L. 1999. Orchids, gaywings and swallowtails. The Advance/Review (2 June 1999): 14A (newspaper article).

Darbyshire, S., and L. L. Consaul. 1999. Wildlife sometimes benefits from Purple Loosestrife. Trail and Landscape 33: 181-184.

Consaul, L. L., A. W. Dugal, and R. Boles. 2001. Leitrim Albion Road Wetlands: Its Biodiversity and its Bio-Blitz. Trail and Landscape 35: 16-61.

Consaul, L. L., and L. J. Gillespie. 2001. A re-evaluation of species limits in Canadian Arctic Island Puccinellia (Poaceae): resolving key characters. Canadian Journal of Botany 79: 927-956.

Consaul, L. L., M. J. Waterway, and P. Seguin. 2003a. Voisey's Bay Mine Site/Anaktalak Bay Exploration Camp. Investigations toward stabilization and revegetation of overburden by native plant species. Report 1: Research on suitable plant species and procedures. For Inco Ltd., January 2003.

Consaul, L. L., S. Darwish, M. J. Waterway, and P. Seguin. 2003b. Voisey's Bay Mine Site/Anaktalak Bay Exploration Camp. Investigations toward stabilization and revegetation of overburden by native plant species. Report 2: Greenhouse Experiments and First Season Field Trials. For Inco Ltd., November 2003.

Consaul, L. L., S. Darwish, M. J. Waterway, and P. Seguin. 2004a. Voisey's Bay Mine Revegetation Project. Report 3: Summary 2002-2003. For Inco Ltd. and Voisey's Bay Nickel Company, February 2004.

Consaul, L. L., P. Seguin, and M. J. Waterway. 2004b. Voisey's Bay Mine Revegetation Project. Report 4: Revegetation plot results, 2003-2004. For Inco Ltd. and Voisey's Bay Nickel Company, August 2004.

Consaul, L. L., P. Seguin, and M. J. Waterway. 2004c. Voisey's Bay Mine Revegetation Project. Report 5: Revegetation results, 2003-2004 - statistics. For Inco Ltd. and Voisey's Bay Nickel Company, November 2004.

Consaul, L. L., L. J. Gillespie, and K. I. MacInnes. 2005. Addition to the flora of Canada? A specimen from the Arctic Archipelago, Northwest Territories links two allopatric species of alkali grass, Puccinellla. The Canadian FieldNaturalist 119: 497-506.

Aiken, S. G., M. J. Dallwitz, L. L. Consaul, C. L. McJannet, R. L. Boles, G. W. Argus, J. M. Gillett, P. J. Scott, R. Elven, M. C. LeBlanc, L. J. Gillespie, A. K. Brysting, H. Solstad, and J. G. Harris. 2007. Flora of the Canadian Arctic Archipelago: Descriptions, Illustrations, Identification, and Information Retrieval. [CD-ROM]. NRC Research Press, Ottawa, Ontario.

Consaul, L. L. 2007. The role of polyploidy in the systematics and evolution of arctic alkali grass (Puccinellia) in North America. Ph.D. dissertation, McGill University, Montreal, Quebec. 
Consaul, L. L., and S. G. Aiken. 2007. Phippsia. Pages 478480 in Magnoliophyta: Commelinidae (in part): Poaceae, Part 1. Edited by M. E. Barkworth, K. M. Capels, S. Long, L. K. Anderton, and M. S. Piep. Vol. 24 of the Flora of North America North of Mexico. Edited by the Flora of North America Editorial Committee. Oxford University Press, New York and Oxford.

Davis, J. I., and L. L. Consaul. 2007a. Puccinellia. Pages 459-477 in Magnoliophyta: Commelinidae (in part): Poaceae, Part 1. Edited by M. E. Barkworth, K. M. Capels, S. Long, L. K. Anderton, and M. S. Piep. Vol. 24 of the Flora of North America North of Mexico. Edited by the Flora of North America Editorial Committee. Oxford University Press, New York and Oxford.

Davis, J. I., and L. L. Consaul. 2007b. Puccinellia. Pages 106-110 in Manual of Grasses for North America. Edited by M. E. Barkworth, L. K. Anderton, K. M. Capels, S. Long, and M. S. Piep. Intermountain Herbarium and Utah State University Press, Logan, Utah.

Consaul, L. L., L. J. Gillespie, and M. J. Waterway. 2008a. A new species of alkali grass (Puccinellia, Poaceae) from the western North American Arctic. Novon 18: 16-20.

Consaul, L. L., L. J. Gillespie, and M. J. Waterway. 2008b. Systematics of North American arctic diploid Puccinellia (Poaceae): morphology, DNA content, and AFLP markers. Systematic Botany 33: 251-261.

Consaul, L. L., L. J. Gillespie, and M. J. Waterway. 2008c. Systematics of three North American polyploid arctic alkali grasses (Puccinellia, Poaceae): morphology, ploidy, and AFLP markers. Botany 86: 916-937.

Chen, X., L. Consaul, J.-Y. Huang, H. Xie, and X. Chen. 2010a. Rhododendron subroseum sp. nov. and $R$. denudatum var. glabriovarium var. nov. (Ericaceae) from the Guizhou Province, China. Nordic Journal of Botany 28: 496498.
Chen, X., L. Consaul, J. Huang, and X. Chen. 2010b. New taxa of Rhododendron (Ericaceae) from China. Annales Botanici Fennici 47: 397-402.

Chen, X., J.-Y. Huang, L. Consaul, and X. Chen. 2010c. Two new species of Rhododendron (Ericaceae) from Guizhou, China. Novon: A Journal for Botanical Nomenclature 20: 386-391.

Consaul, L. L., L. J. Gillespie, and M. J. Waterway. 2010a. Evolution and polyploid origins in North American arctic Puccinellia (Poaceae) based on nuclear ribosomal spacer and chloroplast DNA sequences. American Journal of Botany 97: 324-336.

Consaul, L. L., L. J. Gillespie, and M. J. Waterway. 2010b. Polyploid speciation and evolution in arctic Puccinellia (Poaceae: Puccinelliinae): a review. Pages 645-661 in Diversity, Phylogeny, and Evolution in the Monocotyledons. Proceedings of the Fourth International Conference on the Comparative Biology of the Monocotyledons and the Fifth International Symposium on Grass Systematics and Evolution, held in Copenhagen in 2008. Edited by O. Seberg, G. Petersen, A. Barfod, and J. Davis. Aarhus University Press, Aarhus, Denmark.

Saarela, J. M., L. J. Gillespie, L. L. Consaul, and R. D. Bull. 2011. Balsam Poplar (Populus balsamifera; Salicaceae) beyond the tree line in the western Canadian mainland Arctic (Northwest Territories). Arctic 65: 1-12.

Ferrera-Rodriguez, O., C. Greer, D. Juck, L. Consaul, E. Martinez-Romero, and L. Whyte. 2013. Hydrocarbon degrading potential of microbial communities from Arctic plants. Journal of Applied Microbiology 114: 71-83.

Saarela J. M., L. J. Gillespie, L. L. Consaul, and R. D. Bull. 2013. Annotated checklist to the vascular plant flora of Tuktut Nogait National Park and the Melville Hills region (Canadian Low Arctic). Phytotaxa 102: 1-177. 